\title{
HUBUNGAN FAKTOR-FAKTOR INTERNAL DENGAN KEJADIAN KELELAHAN MENTAL (BURNOUT) PADA PERAWAT
}

\author{
Siti Kholifah ${ }^{1}$, Setyawati Soeharto ${ }^{2}$, Lilik Supriati ${ }^{3}$ \\ ${ }^{1}$ Program Studi Magister Keperawatan Fakultas Kedokteran Universitas Brawijaya \\ 2,3 FakultasKedokteranUnivesitasBrawijaya \\ Jalan Veteran Malang 65145 \\ Email: kholifah71@yahoo.co.id
}

\begin{abstract}
Patient's condition in Intensive Psychiatric Care Unit (IPCU) makes nurses doing 24 hours of observation and always presenting themselves in therapeutic context during their interaction with patients. This kind of routine becomes one of a stressor to the nurses and also drives them to burnout state. Burnout is apparently influenced by both of internal and external factors. Internal factors are significant since each of individual assessment toward external factors is mostly depend on the internal factors. The objective of this research is to analyze the correlation between internal factors and nurses burnout in IPCU Dr. Radjiman Wediodiningrat Mental Hospital of Lawang. This study uses analytic observational design with cross-sectional approach. The sample used was 40 of nurses gained by using purposive sampling method. This research found that there was correlation between emotional maturity and burnout ( $p$ value $=0,001$ and $r=-0,500$ ), psychological well-being and burnout ( $p$ value $=0.000$ and $r=-0,601$ ), self adjustment related to psychological well-being and burnout ( $p$ value $=0.001$ and $r=-0,523$ ). Based on the result of linear regression, it could be concluded that the most dominant factor related to burnout was psychological well-being ( $p$ value < 0,001 and correlation coefficient $=-0.543$ ). This matter was possible to be happened because Dr. Radjiman Wediodiningrat Mental Hospital of Lawang had made various efforts to improve the psychological well-being of the nurses to minimize the incidence of burnout.
\end{abstract}

\section{Keywords: burnout, nurse, psychiatric intensive, internal factors}

Abstrak : Kondisi pasien di Intensive Psychiatric Care Unit (IPCU) menuntut perawat untuk melakukan observasi ketat selama 24 jam serta selalu menghadirkan dirinya dalam konteks terapeutik melalui interaksi dengan pasien. Rutinitas tersebut dapat menjadi stressor bagi perawat sehingga mengalami kelelahan mental atau burnout. Kelelahan mental dapat dipengaruhi oleh faktor internal maupun faktor eksternal. Faktor internal menjadi sangat penting karena penilaian individu terhadap faktor eksternal yang dialami sangat bergantung pada faktor internalnya.Penelitian ini bertujuan untuk menganalisis hubungan faktor-faktor internal dengan kejadian kelelahan mental (burnout) pada perawat di IPCU RSJ Dr Radjiman Wediodiningrat Lawang.Penelitian ini menggunakan desain observasionalanalitik dengan pendekatan cross-sectional. Responden berjumlah 40 orang yang didapatkan dengan metode purposive sampling. Hasil penelitian ini menunjukkan bahwa terdapat hubungan yang bermakna antara kematangan emosi dan kejadian kelelahan mental ( $p$ value $=0,001$ dan $r=-0,500$ ), antara kesejahteraan psikologis dan kejadian kelelahan mental $(p$ value $=0.000$ dan $r=-0,601$ ), serta antara penyesuaian diri dan kejadian kelelahan mental ( $p$ value $=0.001$ dan $r=-0,523$ ). Berdasarkan hasil uji regresi linier disimpulkan bahwa faktor yang paling berhubungan dengan kelelahan mental adalah kesejahteraan psikologis ( $p$ value $<0,001$ dan koefisien korelasi $=-0.543$ ). Hal inidimungkinkankarena RSJ Dr. Radjiman Wediodiningrat Lawang telah melakukan berbagai upaya untuk meningkatkan kesejahteraan psikologis perawat sehingga meminimalisasi kejadian kelelahan mental.

Kata kunci: kelelahan mental, perawat, intensifpsikiatri, faktor interna

\section{PENDAHULUAN}

Perawat merupakan tenaga kesehatan utama di rumah sakit yang menjadi garis terdepan dan memiliki peranan penting dalam pelayanan kesehatan kepada pasien. Pasien yang datang di Intensive Psychiatric Care Unit (IPCU) umumnya menunjukkan berbagai gejala masalah perilaku, seperti perilaku kekerasan, kecenderungan mencederai orang lain, agitasi, dan percobaan bunuh 
diri. Kondisi pasien yang demikian menuntut perawat untuk melakukan observasi ketat selama 24 jam (Winkler, et al., 2010) serta selalu menghadirkan dirinya dalam konteks terapeutik melalui interaksi dengan pasien (Stuart \& Laraia, 2013). Rutinitas tersebut dapat menjadi stressor bagi perawat sehingga mengalami kelelahan mental atau burnout (Wang, et al., 2014; Yang, Meredith \& Khan, 2015).

Perawat yang bekerja di bagian psikiatrik memiliki resiko yang tinggi untuk mengalami kelelahan mental (Chakraborty, Chatterjee, \& Chaudhury, 2012). Beberapa penelitian mengindikasikan bahwa angka kejadian perawat jiwa mengalami kelelahan mental lebih tinggi dibandingkan perawat dari bagian yang lain (Madathil, Heck \& Schuldberg, 2014). Berdasarkan penelitian yang dilakukan oleh Fuente et al (2014), prevalensi terjadinya kelelahan mental pada perawat jiwa di Spanyol cukup tinggi dimana sepertiga dari total responden mengalami kelelahan mental dengan rata-rata $25 \%$ pada dimensi kelelahan emosi, $30 \%$ pada dimensi depersonalisasi, dan $45 \%$ pada dimensi prestasi diri. Hasil yang sama ditunjukkan dalam penelitian Acker (2012) terhadap 460 perawat jiwa di Amerika Serikat bahwa $56 \%$ di antaranya mengalami kelelahan emosi, dan $73 \%$ mengalami stres pada level sedang.

$$
\text { Kelelahan mental dapat }
$$

dipengaruhi oleh faktor internal maupun faktor eksternal. Faktor internal yang dimaksud adalah faktor yang ada dalam diri perawat sendiri, seperti kematangan emosi, kesejahteraan psikologis, dan penyesuaian diri. Sedangkan faktor eksternal merupakan faktor yang berasal dari lingkungan kerja, seperti beban kerja dan pengaturan shift. Berdasarkan beberapa penelitian, faktor eksternal terbukti memiliki hubungan yang signifikan dengan kelelahan mental (Fuente, et al., 2014; Vargas, et al., 2013; Bogaert, et al., 2013). Namun sangat penting untuk mengetahui faktor internal karena penilaian individu terhadap faktor eksternal yang dialami sangat bergantung pada bagaimana faktor internalnya.
Dengan kata lain, sangat penting mengetahui mengapa seseorang lebih rentan mengalami kelelahan mental dibandingkan orang lain (Madathil, Heck \& Schuldberg, 2014). Hal ini sesuai dengan penelitian Hsieh dan Wang (2012) yang menunjukkan hasil bahwa faktor internal memiliki signifikansi yang lebih tinggi daripada faktor eksternal dalam menentukan resiko seseorang untuk mengalami kelelahan mental.

Berdasarkan observasi yang dilakukan oleh peneliti di Ruang IPCU Camar RSJ Dr Radjiman Wediodiningrat Lawang Kabupaten Malang, alasan utama pasien dirawat di ruangan ini adalah memiliki indikasi perilaku kekerasan,kecenderungan mencederai orang lain, agitasi, dan percobaan bunuh diri. Kondisi pasien yang demikian menjadikan perawat memiliki beban yang lebih berat dibandingkan dengan perawat di ruang perawatan yang lain. Perawat dituntut terlibat secara aktif dalam melakukan penanganan pasien dengan kondisi krisis meliputi tindakan pengekangan (restrain), pemberian obat dan pemberian psikoterapi. Hasil wawancara dengan 3 orang perawat di ruangan tersebut menunjukkan bahwa 2 dari 3 perawat terkadang merasa takut dan tidak mampu menangani pasien apabila pasien dalam kondisi sangat tidak stabil. Selain itu, perawat juga terkadang merasa lelah dan tidak mood apabila jumlah pasien yang ditangani cukup banyak.Berdasarkan fenomena tersebut, peneliti tertarik untuk melakukan penelitian tentang hubungan faktor-faktor internal dengan kejadian kelelahan mental (burnout) pada perawat di IPCU RSJ Dr Radjiman Wediodiningrat Lawang.

\section{METODE PENELITIAN}

Penelitian ini menggunakan desain observasionalanalitik dengan pendekatan cross-sectional. Responden berjumlah 40 orang yang didapatkan dengan metode purposive sampling. Penelitian dilaksanakan pada bulan Mei sampai dengan Juni 2016. Instrumen yang digunakan dalam penelitian ini adalah Emotional Maturity Scale (EMS) untuk 
mengukur kematangan emosi, Ryff Scale of Psycholo-gical Well-Being untuk mengukur kesejahteraan psikologis, Global Adjusment Scale (GAS) untuk mengukur penyesuaian diri , dan Maslach Burnout Inventory (MBI) untuk mengukur kelelahan mental (burnout).

Analisa data yang digunakan dalam penelitian ini adalah analisis bivariat menggunakan uji Spearman Rank untuk mengetahui hubungan factor kematangan emosi dan kesejahteraan psikologis terhadap kejadian kelelahan mental, serta uji Pearson untuk mengetahui hubungan penyesuaian diri dengan kejadian kelelahan mental. Sedangkan analisis multivariate menggunakan regresi linier untuk mengetahui faktor yang paling berhubungan dengan kejadian kelelahan mental.

\section{HASIL PENELITIAN}

Hasil penelitian karakteristik responden berdasarkan usia dan lama kerja didapatkan bahwa rata-rata usia responden adalah 38,38 tahun yang termasuk dalam kategori usia dewasa awal. Sedangkan rata-rata lama kerja responden adalah 3,43 tahun.

Tabel 2. Karakteristik Faktor Intenal

\begin{tabular}{lccccc} 
& $\mathrm{n}$ & Median & Min-Max & Mean & SD \\
\hline Kematangan Emosi & 40 & 156 & $142-178$ & 155.03 & 9.580 \\
\hline Kesejahteraan Psikologis & 40 & 49.50 & $36-58$ & 48.65 & 7.195 \\
\hline Penyesuaian Diri & 40 & 73 & $61-86$ & 73 & 7.186 \\
\hline
\end{tabular}

Berdasarkan tabel 2 didapatkan bahwa rata-rata kematangan emosi responden adalah 155,03 yang termasuk dalam kategori kematangan emosi tinggi. Rata-rata kesejahteraan psikologis
Tabel 1. Karakteristik Responden

Berdasarkan JenisKelamin, Status

Perkawinan dan Tingkat Pendidikan

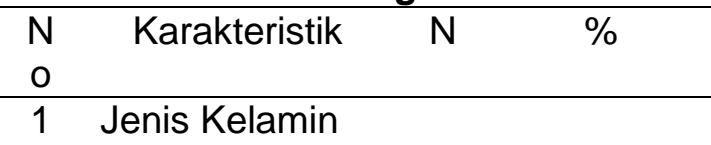

a. Laki-laki $27 \quad 67.5 \%$

b. Perempuan $13 \quad 32.5 \%$

2 Status

Perkawinan

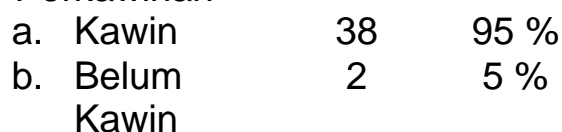

3 Tingkat

Pendidikan

\begin{tabular}{llcc} 
a. & SPK & 2 & $5 \%$ \\
b. & Diploma III & 23 & $57.5 \%$ \\
c. & Diploma IV & 4 & $10 \%$ \\
d. & Sarjana & 11 & $27.5 \%$ \\
\hline
\end{tabular}

Berdasarkan tabel 1 didapatkan bahwa responden terbanyak berjenis kelamin laki-laki sebanyak 27 orang $(67,5 \%)$, memiliki status telah kawin sebanyak 38 orang (95\%), dan memiliki tingkat pendidikan Diploma III Keperawatan sebanyak 23 orang (57,5\%).

Tabel 3. Karakteristik Kelelahan Mental

(Burnout)

\begin{tabular}{lccccc}
\hline & \multicolumn{5}{c}{ Mini-Max } \\
& $\mathrm{n}$ & Median & & Mean & SD \\
\hline Kejadian Kelelahan Mental & 40 & 40 & $33-45$ & 39.58 & 2.352 \\
\hline
\end{tabular}

bahwa rata-rata kelelahan mental

termasuk dalam kategori tidak mengalami

(burnout) responden adalah 39,58 yang

responden adalah 48,65 yang termasuk dalam kategori kesejahteraan psikologis tinggi. Rata-rata penyesuaian diri responden adalah 73 yang termasuk dalam kategori penyesuaian diri baik.

\section{burnout.}


Tabel 4. Hubungan Kematangan Emosi dengan Kelelahan Mental (Burnout)

\begin{tabular}{lcc}
\hline & & $\begin{array}{c}\text { Kelelahan Mental } \\
\text { (Burnout) }\end{array}$ \\
\hline Kematangan & $\mathrm{r}$ & -0.500 \\
Emosi & $\mathrm{p}$ & 0.001 \\
& $\mathrm{n}$ & 40 \\
\hline
\end{tabular}

Berdasarkan tabel 4 didapatkan $p$ value 0.001 yang menunjukkan bahwa korelasi antara kematangan emosi dan kelelahan mental (burnout) adalah bermakna. Nilai korelasi Spearman sebesar -0,500 menunjukkan bahwa arah korelasi negatif dengan kekuatan korelasi sedang. Hal ini berarti semakin tinggi kematangan emosi seseorang maka semakin rendah kelelahan mental (burnout) yang dialami, demikian juga sebaliknya.

Tabel 5. Hubungan Kesejahteraan Psikologis dengan Kelelahan Mental (Burnout)

\begin{tabular}{lcc}
\hline & & $\begin{array}{c}\text { Kelelahan Mental } \\
\text { (Burnout) }\end{array}$ \\
\hline $\begin{array}{l}\text { Kesejahteraan } \\
\text { Psikologis }\end{array}$ & $\mathrm{r}$ & -0.601 \\
& $\mathrm{p}$ & $<0.001$ \\
& $\mathrm{n}$ & 40 \\
\hline
\end{tabular}

Berdasarkan tabel 5 didapatkan $p$ value 0.000 yang menunjukkan bahwa korelasi antara kesejahteraan psikologis dan kelelahan mental (burnout) adalah bermakna. Nilai korelasi Spearman sebesar -0,601 menunjukkan bahwa arah korelasi negatif dengan kekuatan korelasi kuat. Hal ini berarti semakin tinggi kesejahteraan psikologis seseorang maka semakin rendah kelelahan mental (burnout) yang dialami, demikian juga sebaliknya

\section{Tabel 6. Hubungan Penyesuaian Diri} dengan Kelelahan Mental (Burnout)

\begin{tabular}{lcc}
\hline & & $\begin{array}{c}\text { Kelelahan Mental } \\
(\text { Burnout })\end{array}$ \\
\hline Penyesuaian & $\mathrm{r}$ & -0.523 \\
Diri & $\mathrm{p}$ & 0.001 \\
& $\mathrm{n}$ & 40 \\
\hline
\end{tabular}

Berdasarkan tabel 6 didapatkan $p$ value 0.001 yang menunjukkan bahwa korelasi antara penyesuaian diri dan kelelahan mental (burnout) adalah bermakna. Nilai korelasi Pearson sebesar -0,523 menunjukkan bahwa arah korelasi negatif dengan kekuatan korelasi sedang. $\mathrm{Hal}$ ini berarti semakin baik penyesuaian diri seseorang maka semakin rendah kelelahan mental (burnout) yang dialami, demikian juga sebaliknya.

Tabel 7. Hasil Analisis Regresi Linier

\begin{tabular}{clccc}
\hline \multicolumn{1}{c}{ Langkah } & \multicolumn{1}{c}{ Variabel } & Koefisien & Koefisien Korelasi & P value \\
\hline Langkah 1 & Kematangan Emosi & -0.064 & -0.261 & 0.074 \\
& Kesejahteraan & -0.179 & -0.547 & 0.003 \\
& $\begin{array}{l}\text { Psikologis } \\
\text { Penyesuaian Diri }\end{array}$ & 0.002 & 0.008 & 0.968 \\
& & & \\
\hline Langkah 2 & Kematangan Emosi & -0.064 & -0.259 & 0.054 \\
& Kesejahteraan & -0.178 & -0.543 & $<0.001$ \\
& Psikologis & & & \\
\hline
\end{tabular}

Berdasarkan tabel 7 disimpulkan bahwa variabel yang dapat digunakan untuk memprediksi kelelahan mental (burnout) adalah variabel kematangan emosi dan kesejahteraan psikologis. Dari kedua faktor internal tersebut yang paling kuat hubungannya dengan kejadian kelelahan mental (burnout) adalah kesejahteraan psikologis dengan $p$ value $<$ 0,001 dan koefisien korelasi -0,543.
Adapun persamaan regresi yang didapatkan adalah:

$\mathrm{Y}=$ konstanta $+\mathrm{ax} 1+\mathrm{ax} 2$

Kelelahan mental (burnout) $=58,079-$ 0,064 (kematangan emosi) - 0,178 (kesejahteraan psikologis)

Berdasarkan hasil ANOVA didapatkan nilai $\mathrm{p}<0.05$ sehingga persamaan tersebut di atas layak untuk digunakan. Sedangkan berdasarkan 
Model Summary didapatkan nilai adjusted $R$ square sebesar $45 \%$ artinya persamaan yang diperoleh mampu menjelaskan kejadian kelelahan mental (burnout) sebesar $45 \%$. Sisanya sebesar 55\% dijelaskan oleh variabel lain yang tidak diteliti.

\section{PEMBAHASAN}

\section{Hubungan Kematangan Emosi dengan Kejadian Kelelahan Mental (Burnout)}

Berdasarkan hasil uji Spearman Rank didapatkan $p$ value 0.001 yang menunjukkan bahwa hubungan antara kematangan emosi dan kejadian kelelahan mental (burnout) adalah bermakna. Nilai korelasi Spearman sebesar -0,500 menunjukkan bahwa arah korelasi negatif dengan kekuatan korelasi sedang. Hal ini berarti semakin tinggi kematangan emosi seseorang maka semakin rendah kelelahan mental (burnout) yang dialami, demikian juga sebaliknya.

Hasil yang sama didapatkan dari penelitian yang dilakukan oleh Rohmah (2010) pada perawat di salah satu rumah sakit swasta di Jawa Timur yang menyatakan bahwa antara kematangan emosi dengan burnout memiliki korelasi yang signifikan, dimana kematangan emosi perawat berada pada kategori sedang, demikian juga dengan burnout yang dialami. Hubungan antara kematangan emosi dan burnout juga didukung dengan hasil penelitian yang telah dilakukan oleh Hanafi dan Yuniasanti (2012)bahwa terdapat hubungan negatif yang sangat signifikan antarakematangan emosi dengan burnout pada perawat di salah satu rumah sakit swasta di Yogyakarta. Artinya semakin tinggi kematangan emosi perawat maka burnout cenderung rendah dan sebaliknya, semakin rendah kematangan emosi perawat, maka kecenderungan burnout menjadi tinggi.

Orang yang memiliki kematangan emosidapat menempatkan diri seirama dengan kenyataan-kenyataan yang dihadapi dalam situasi baru. Beberapa ciri kematangan emosi seseorang antara lain: mampu menerima baik keadaan dirinya maupun keadaan orang lain seperti adanya sesuai dengan keadaan obyektifnya. Hal ini disebabkan, seseorang yang memiliki kematangan emosi dapat berpikir secara lebih baik dan obyektif. Orang itu tidak akan bersifat impulsif, mampu merespon stimulus dengan cara berpikir baik serta sanggup mengatur pikirannya untuk memberikan tanggapan terhadap stimulus yang mengenainya. Seseorang dengan kematangan emosi mampu mengontrol emosi dan mengekspresikan emosinya secara baik pula. Orang tersebut biasanya bersifat sabar, penuh pengertian dan umumnya memiliki toleransi cukup baik, bertanggungjawab,mandiri, tidak mudah mengalami frustrasi sertamenghadapi masalah dengan penuh pengertian (Hanafi \& Yuniasanti, 2012).

$$
\text { Melalui kematangan emosi, }
$$

seorang perawat kemungkinan dapat memfokuskan perhatian pada fakta-fakta penting dari masalah yang dihadapi. Hal tersebut akan membentuk kemampuan baik dalam memecahkan masalah, meminimalisir dan menghindarkan diri dari kemungkinan mengalami perasaan cemas, tertekan serta ketidaknyamanan emosional yang berujung burnout. Apabila seorang perawat memiliki tingkat kematangan emosi yang semakin tinggi, makaburnout akan semakin rendah (Hanafi \& Yuniasanti, 2012).

\section{Hubungan Psikologis dengan Kejadian Kelelahan Mental (Burnout)}

Berdasarkan hasil uji Spearman Rank didapatkan $p$ value 0.000 yang menunjukkan bahwa korelasi antara kesejahteraan psikologis dan kejadian kelelahan mental (burnout) adalah bermakna. Nilai korelasi Spearman sebesar -0,601 menunjukkan bahwa arah korelasi negatif dengan kekuatan korelasi kuat. Hal ini berarti semakin tinggi kesejahteraan psikologis seseorang maka semakin rendah kelelahan mental (burnout) yang dialami, demikian juga sebaliknya. Semakin rendah 
kesejahteraan psikologis seseorang maka semakin tinggi kelelahan mental (burnout) yang dialami.

Kelelahan mental (burnout) memiliki hubungan yang erat dengan kondisi kesejahteraan psikologis seseorang. Berdasarkan penelitian yang dilakukan oleh Chakraborty, Chatterjee, dan Chaudhury (2012) pada perawat jiwa di India didapatkan hasil bahwa seseorang yang memiliki kesejahteraan psikologis yang baik dan tidak memiliki riwayat masalah kejiwaan sebelumnya dapat terhindar dari kelelahan mental. Seluruh responden dalam penelitian tersebut tidak memiliki riwayat masalah kejiwaan sebelumnya sehingga tidak ada faktor perancu.

Ryff (1995) menyebutkan bahwa kesejahteraan psikologis merupakan suatu konsep yang berkaitan dengan apa yang dirasakan individu mengenai aktivitas dalam kehidupan sehari-hari serta mengarah pada pengungkapan perasaan pribadi atas apa yang dirasakan oleh individu sebagai hasil dari pengalaman hidupnya. Kesejahteraan psikologis dapat ditandai dengan diperolehnya kebahagiaan, kepuasan hidup dan tidak adanya tanda-tanda depresi. Berdasarkan konsep tersebut maka perawat yang memiliki kesejahteraan psikologis tinggi tidak akan menunjukkan tanda-tanda kelelahan mental (burnout).

\section{Hubungan Penyesuaian Diri dengan Kejadian Kelelahan Mental (Burnout)}

Berdasarkan hasil uji Pearson didapatkan $p$ value 0.001 yang menunjukkan bahwa korelasi antara penyesuaian diri dan kejadian kelelahan mental (burnout) adalah bermakna. Nilai korelasi Pearson sebesar $-0,523$ menunjukkan bahwa arah korelasi negatif dengan kekuatan korelasi sedang. Hal ini berarti semakin tinggi penyesuaian diri seseorang maka semakin rendah kelelahan mental (burnout) yang dialami, demikian juga sebaliknya.

Hasil yang serupa didapatkan dalam penelitian yang dilakukan oleh
Normadiansyah (2010) terhadap perawat di salah satu rumah sakit swasta di Jawa Timur. Penelitian tersebut menunjukkan bahwa terdapat hubungan yang signifikan antara tingkat penyesuaian diri dan tingkat konflik kerja perawat. Arah hubungan yang dihasilkan adalah negatif, yang artinya semakin tinggi tingkat penyesuaian diri perawat maka kemungkinan konflik kerja yang dialami akan semakin rendah.

Seseorang dikatakan mampu menyesuaikan diri apabila memiliki kemampuan memenuhi kebutuhan dari dalam dirinya dan tuntutan lingkungannya serta mampu mengatasi hambatan yang dihadapinya. Penyesuaian diri yang positif akan memberikan kepuasan lebih besar bagi kehidupan seseorang dan juga dapat mempelancar fungsi efektivitas psikis yang bermacam-macam seperti belajar, menentukan tujuan hidup, atau juga di dalam penyelesaian masalah.

Hal ini didukung dengan pendapat yang dikemukakan oleh Hurlock (2000) bahwa keberhasilan individu dalam melakukan penyesuaian diri menimbulkan perasaan puas dan menumbuhkan rasa percaya diri. Unsur-unsur pendukung dalam penyesuaian diri antara lain yaitu kemampuan mengatasi tekanan kebutuhan, kemampuan yang layak untuk mengatasi frustasi dan kemampuan mengembangkan mekanisme psikologis yang cocok.

\section{Faktor yang Paling Berhubungan dengan Kelelahan Mental}

Berdasarkan hasil uji regresi linier didapatkan bahwa variabel yang dapat digunakan untuk memprediksi kelelahan mental (burnout) adalah variabel kematangan emosi dan kesejahteraan psikologis. Dari kedua faktor internal tersebut yang paling kuat hubungannya dengan kejadian kelelahan mental (burnout) adalah kesejahteraan psikologis dengan $p$ value $<0,001$ dan koefisien korelasi -0,543. Adapun persamaan regresi yang didapatkan adalah:

Kelelahan mental (burnout) $=58,079-$ 0,064 (kematangan emosi) - 0,178 (kesejahteraan psikologis) 
Berdasarkan hasil ANOVA didapatkan $p$ value $<0.05$ sehingga persamaan tersebut di atas layak untuk digunakan memprediksi kelelahan mental (burnout) pada perawat di IPCU RSJ Dr. Radjiman Wediodiningrat Lawang. Selain itu, berdasarkan Model Summary didapatkan nilai adjusted $R$ square sebesar $45 \%$ artinya persamaan yang diperoleh mampu menjelaskan kejadian kelelahan mental (burnout) sebesar $45 \%$. Sisanya sebesar $55 \%$ dijelaskan oleh variabel lain yang tidak diteliti. Hal ini menjelaskan bahwa faktor internal memiliki kontribusi yang cukup tinggi terhadap kejadian burnout.

Kematangan emosi dan kesejahteraan psikologis memiliki kontribusi terhadap kejadian burnout yang dialami oleh perawat di IPCU RSJ Dr. Radjiman Wediodiningrat Lawang. Hasil ini konsisten dengan hasil penelitian sebelumnya yang menyatakan bahwa kematangan emosi dan kesejahteraan psikologis merupakan prediktor internal kejadian burnout pada perawat (Chakraborty, Chatterjee \& Chaudury, 2012). Penelitian yang lain menyebutkan bahwa burnout pada perawat berhubungan dengan tingginya gejala psikosomatis, tingginya penggunaan obatobatan, serta rendahnya kepuasan hidup (Burke, 2010).

Seseorang dengan kesejahteraan psikologis yang tinggi mampu menerima kondisi dirinya apa adanya, mampu menjalin hubungan yang hangat dan saling percaya dengan orang lain, mampu mengatur dirinya sendiri dan mampu memanipulasi lingkungan sesuai dengan nilai-nilai pribadi yang dimiliki, memiliki tujuan hidup yang jelas serta mampu mengembangkan aspek positif dalam dirinya (Lianawati, 2008). Kesejahteraan psikologis kemudian direfleksikan dalam bentuk tercapainya kebahagiaan, kepuasan hidup dan tidak adanya tandatanda depresi (Ryff, 1995) sehingga pada perawat yang memiliki kesejahteraan psikologis tinggi tidak akan ditemukan tanda-tanda kelelahan mental (burnout).

Kelelahan mental (burnout) dapat diprediksi oleh $55 \%$ faktor lain yang tidak diteliti dalam penelitian ini. Faktor lain tersebut dapat berupa faktor internal, misalnya religiusitas, mekanisme koping, dan tipe kepribadian (Vorkapic \& Mustapic, 2012; Doolittle, Windish, \& Seelig, 2012), atau faktor eksternal, misalnya beban kerja, kepuasan kerja, dan manajemen ruangan (Vargas et al., 2013).

Hasil penelitian ini menunjukkan
bahwa kematangan emosi dan kesejahteraan psikologis perawat di IPCU RSJ Dr. Radjiman Wediodiningrat Lawang dalam kategori tinggi sehingga kejadian kelelahan mental (burnout) yang dialami rendah. Hal ini dimungkinkan karena manajemen rumah sakit telah melakukan berbagai upaya untuk meminimalkan kejadian kelelahan mental (burnout), seperti menjamin kesejahteraan perawat, menerapkan prosedur perekrutan dan penempatan perawat, melakukan rotasi dinas ruangan secara berkala, serta melaksanakan program pembinaan diri seperti capacity buiding secara bergantian dan berkelanjutan.

\section{KESIMPULAN DAN SARAN}

\section{Kesimpulan}

Berdasarkan hasil penelitian ini dapat disimpulkan bahwa:

1) Perawat di IPCU RSJ Dr. Radjiman Wediodiningrat Lawang mempunyai rata-rata usia 38,38 tahun dan lama kerja 3,43 tahun, serta terbanyak berjenis kelamin laki-laki sebesar $67,5 \%$, telah kawin sebesar 95\% dan tingkat pendidikan Diploma III Keperawatan sebesar $57,5 \%$.

2) Perawat di IPCU RSJ Dr. Radjiman Wediodiningrat Lawang mempunyai rata-rata kematangan emosi tinggi $(155,03)$, kesejahteraan psikologis tinggi $(48,65)$, dan penyesuaian diri baik (73).

3) Perawat di IPCU RSJ Dr. Radjiman Wediodiningrat Lawang mempunyai rata-rata kelelahan mental (burnout) 39,58 yang termasuk dalam kategori tidak mengalami burnout.

4) Kematangan emosi berhubungan dengan kejadian kelelahan mental (burnout) pada perawat di IPCU RSJ 
Dr. Radjiman Wediodiningrat Lawang dengan kekuatan korelasi sedang dan arah yang negatif.

5) Kesejahteraan psikologis berhubungan dengan kejadian kelelahan mental (burnout) pada perawat di IPCU RSJ Dr. Radjiman Wediodiningrat Lawang dengan kekuatan korelasi kuat dan arah yang negatif.

6) Penyesuaian diri berhubungan dengan kejadian kelelahan mental (burnout) pada perawat di IPCU RSJ Dr. Radjiman Wediodiningrat Lawang dengan kekuatan korelasi sedang dan arah yang negatif.

7) Kesejahteraan psikologis merupakan faktor internal yang memiliki hubungan paling kuat dengan kejadian kelelahan mental (burnout) pada perawat di IPCU RSJ Dr. Radjiman Wediodiningrat Lawang.

\section{Saran}

Berdasarkan hasil penelitian ini maka dapat disarankan:

\section{DAFTAR PUSTAKA}

Acker, G. M. (2012). Burnout among mental health care providers. Journal of Social Work. 12 (5)

BadanLitbangDepKes

RI.

(2013). Risetkesehatandasartahun 2013. Jakarta:Depkes RI

Berger, A. (2010). Happiness at work. USA: Basil and Spice

Bogaert, P. V., et al. (2013). The relationship between nurse practice environment, nurse work characteristics, burnout and job outcome and quality of nursing care: A cross-sectional survey. International Journal of Nursing Studies. 50 (1)

Chakraborty, R., Chatterjee, A., \& Chaudhury, S. (2012). Internal predictors of burnout in psychiatric nurses: An Indian study. Industrial Psychiatry Journal. 21 (2)

Doolittle, B.R., Windish, D.M., \& Seeling, C.B. (2012). Burnout, coping, and spirituality among internal medicine
1) RSJ Dr. Radjiman Wediodiningrat Lawang diharapkan dapat mempertahankan dan meningkatkan upaya-upaya yang telah dilakukan selama ini untuk meminimalkan kelelahan mental (burnout).

2) Kematangan emosi dan kesejahteraan psikologis dapat menjadi salah satu kriteria dalam penempatan perawat untuk bekerja di IPCU RSJ Dr. Radjiman Wediodiningrat Lawang.

3) Hasil penelitian ini dapat digunakan sebagai data dasar penelitian selanjutnya tentang faktor internal yang berhubungan dengan kejadian kelelahan mental (burnout) pada perawat IPCU yang menganalisis faktor internal lainnya, seperti religiusitas dan tipe kepribadian. Penelitian selanjutnya juga dapat dikembangkan dengan menggali hubungan faktor eksternal dengan kejadian kelelahan mental (burnout) pada perawat IPCU.

resident psysicians. Journal of Graduate Medical Education. 43 (2)

Fuente, et al. (2014). Risk factors and prevalence of burnout syndrome in the nursing profession. International Journal of Nursing Studies. 52 (1)

Hanafi, M., \& Yuniasanti, R. (2012). Hubungan antara kematangan emosi dan burnout pada perawat Rumah Sakit PKU Muhammadiyah Bantul Yogyakarta. Insight. 10 (1)

Hsieh, Y.H., \& Wang, M.L. (2012). The moderating role of personality in HRM: From the influences of job stress on job burnout perspective. International Management Review. $12(1)$

Hurlock, E.B. (2000). Psikologi perkembangan: Suatu pendekatan sepanjang rentang kehidupan. Edisi Kelima. Jakarta: Erlangga 
Madathil, R., Heck, N. C., \& Schuldberg, B. (2014). Burnout in psychiatric nursing: Examining the interplay of autonomy, leadership style and depressive symptoms. Archives of Psychiatric Nursing. 28 (1)

Normadiansyah, A. (2010). Hubungan antara tingkat penyesuaian diri dengan tingkat konflik kerja pada perawat di RSUD Ibnu Sina Gresik. Gresik: Universitas MUhammadiyah

Ryff, C. (1995). Happiness is everything, or is it? Explorations on the meaning of psychological well-being.Journal of Personality and Social Psychology. 57 (1)

Stuart, G.W., \&Laraia, M.T. (2013).Principles and practice of pschyatric nursing-10th ed. United States of Amerika: Mosby Elsevier.

Vargas, et al. (2013). Which occupational risk factors are associated with burnout in nursing? A meta analytic studi. International Journal of Clinical and Health Psychology. 14 (1)

Vorkapic, S.T., \& Mustapic, J. (2012). Internal and external factors in professional burnout of substance abuse consellors in Croatia. Ann Ist Super Sanita. 48 (2)

Wang, et al. (2014). The relationship among work stress, resourcefulness and depression level in psychiatric nurses. Archives of Psychiatic Nursing. 29 (1)

Winkler, et al. (2010). Intensive care in psychiatry. European Psychiatry. (26) 1

Yang, S., Meredith, P., Khan, A. (2015). Stress and burnout among healthcare professionals working in a mental health setting in Singapore. Asian Journal of Psychiatry. $\quad 15$ 